Copyright (C) 2019 by Academic Publishing House Researcher

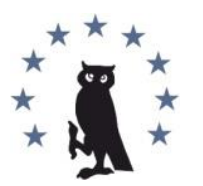

Published in the Russian Federation

European Researcher. Series A

Has been issued since 2010.

E-ISSN 2224-0136

2019, 10(2): 125-130

DOI: 10.13187/er.2019.2.125

www.erjournal.ru

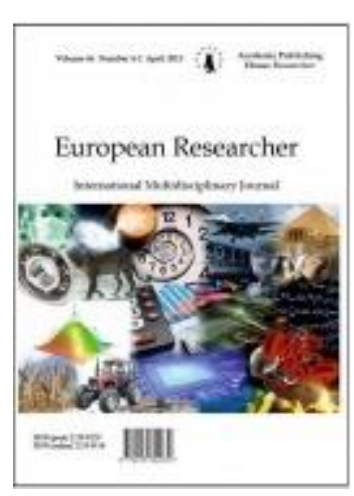

\title{
About Alternative Ways of Attracting Investment
}

\author{
Marietta D. Shapsugova a, * \\ ${ }^{a}$ Institute of State and Law, Russian Academy of Sciences, Russian Federation
}

\begin{abstract}
Digitization of the economy leads to the elimination of mediation and the transition to a peer-to-peer economy. The proliferation of digital platforms catalyzes this investment process. Crowdinvesting is also a tool for diversifying the investment portfolio. The article discusses the current issues of the development of crowdfunding in Russia. Crowdfunding is an alternative source of financing for small and medium-sized businesses that have difficulty obtaining bank loans. At the same time, in the Russian Federation, there is no special legislation regulating crowdfunding activities. A bill on attracting investments using investment platforms is under consideration in the State Duma of the Federal Assembly. The article analyzes its provisions. The main types of crowdfunding are investigated: investment and non-investment models. The experience of legal regulation and implementation of crowdfunding in the United States of America is given.

Keywords: crowdfunding, crowdinvesting, investment, small and medium business, peerto-peer economy

\section{Introduction}

As the small and medium enterprises are the primary sector and the basis for the formation of the middle class experiences difficulties with obtaining bank loans, the state needs to create a legal framework for attracting alternative sources of investment to small and medium businesses. Regulatory bodies, realizing the public interest in the development of small and medium-sized businesses, are taking steps that liberalize the sphere of collective investment.

One of the trends in the digital economy is the elimination of mediation (peer-to-peer economy) through the creation and development of electronic platforms - platforms and aggregators. A similar process has affected the scope of investment. Here, all the more widespread Fintech and investment platforms through which an investor can invest in an investment project.
\end{abstract}

\section{Materials and Methods}

The major source of this article is the draft laws № 419090-7 "On attracting investments using investment platforms"and № 419059-7 "About digital financial assets", the Strategy for the Development of Small and Medium-Sized Businesses in the Russian Federation for the period until 2030, the Jumpstart Our Business Startups Act ( JOBS Act). The article uses comparative method.

\footnotetext{
* Corresponding author

E-mail addresses: shapsugova@gmail.com (M.D. Shapsugova)
} 


\section{Discussion}

One type of investment is retail investment, or micro-investment, not quite right sometimes identified with crowdfunding. More precisely the name of this type of investment can be considered "equity crowdfunding".

Trust has always been the arbiter of success. The cornerstone of trust has always been liquidity, transparency, efficiency, safety, honesty, reliability. In P2P, trust is built on the simplicity of the interface and operation, accessibility, speed and maneuverability, focus and idea (The Americas Alternative Finance...).

Along with the traditional ways of investing receive alternative. One of the alternative ways of investing is online platforms. Such investment methods are the most relevant for beginning small and medium businesses. It is difficult for them to obtain a bank loan. On the other hand, crowdinvesting allows investors to diversify their investment portfolio of high-risk and, therefore, highly profitable assets. Because crowdinvesting can be attributed to microinvestment, the risk of non-return on invested funds is not so frightening.

Investment through an online platform involve certain risks, which include: peculiar startups risks of failure and closure of business, information asymmetry, cybersecurity, fraud risks, and money laundering via online platforms, the risks of closure or incorrect operation of the platform, the risks of illiquidity of the assets acquired through an online platform .

The specified risks can be overcome through appropriate legal regulation:

- Establishments of a special legal status of online investment platforms

- Definition of the legal status of investment participants

- Approval of identification and authentication rules of the investment platform users

- Development of legal mechanisms for making deals using digital platforms

- Responsibility for obligation default

- Guarantees of the rights of investors: temporary account, an extension of consumer protection laws on individual retail investors, etc.

Features of microinvestment using crowdfunding mechanisms can be considered the limit of investment amount into time period. As it will be shown below, the legislation of foreign countries also contains restrictions on the volume of investment and on the amount of the investor's income.

The great popularity in the sphere of microinvestment is gained by a crowdinvesting with use of investment platforms.

The development of new instruments for financing small and medium enterprises is mentioned in Part 4 of Chapter IV of the Strategy for the Development of Small and Medium-Sized Businesses in the Russian Federation for the period until 2030, approved by order of the Government of the Russian Federation of 02.06.2016 № 1083-p (Government of Russian Federation). Thus, collective financing (crowdfunding and crowdinvesting) is considered in the Strategy as an alternative source of financing for projects of small and medium-sized businesses in the early stages of development.

The draft law № 419090-7 "On attracting investments using investment platforms" is under consideration in the State Duma of the Federal Assembly of Russian Federation (draft law on investment platforms) (State Duma of the Federal Assembly of Russia). Previously, it was called "On alternative ways to attract investment (crowdfunding)". The name change is justified since crowdfunding is not only an investment tool; it is also widely used in charity.

The investment platform in this bill is an information system in the Internet used to organize retail financing (crowdfunding).

The draft law uses the term "retail financing", which is not quite successful, does not reflect the essence of investment, the content of which is not equal to the content of the category "investment", since financing can also be repayable and non-repayable, compensable and gratuitous. In the explanatory note to the draft law, the authors emphasize that the draft law covers only those types of crowdfunding, which are related to obtaining financial results for the investment by the investor, and do not regulate the types associated with the donation of funds (donation of property). In this case, it would be more logical using the term "equity crowdfunding."

According to the plan of the developers of the draft law, the operator's investment platform can only be a business entity engaged in the organization of retail financing (crowdfunding) through an investment platform. Such activity refers to the provision of services to provide investors and investment attractors with access to a platform for signing a contracts using this 
platform, based on which investments are made (services for organizing retail financing (crowdfunding).

According to the draft law, participants of the investment platform are investors, and individuals who attract investments.

The investment process is mediated by the conclusion of two types of contracts: on the provision of investment attraction services and the provision of investment promotion services concluded with the operator of the investment platform.

The draft law also operates with the concepts of "token" and "smart contract", with the proviso that these terms are used in this law in a sense defined in the legislation of the Russian Federation. This instruction connects a draft law on investment platforms with other developers of the bill included in a package of bills, which are these definitions - of draft law № 419059-7 "About digital financial assets" (CFA draft law) (State Duma of the Federal Assembly of Russia).

The CFA draft law defines a token as a type of digital financial asset that is issued by a legal entity or an individual entrepreneur (issuer) in order to raise funds and is recorded in the digital transaction registry. A smart contract also means a contract in electronic form, the perfomance of rights and obligations under which is carried out by automatically digital transactions in a distributed ledger of digital transactions in a sequence strictly defined by such an agreement and upon the occurrence of certain circumstances.

This definition of a digital financial asset appears to be very narrow since distributed ledger and tokens can be used not only to raise funds but also for charitable, corporate and other nonfinancial purposes.

Further, in the text of the draft law on investment platform, the term "smart-contract" is almost not mentioned. However, art. 9 of this draft law is devoted to the specifics of signing contracts using the investment platform. Contracts between the participants of the investment platform are signed using hardware and software to access the information contained in the databases of the investment platform. Following Part 3 of this article, actions aimed at establishing, modifying and terminating the rights and obligations of participants in an investment platform can be performed using smart-contracts.

Through the investment platform, an investor can purchase investment project tokens denoting the following property rights (part 2 of article 5 of the draft law):

1) the rights (requirements) of the loan agreement granted to the person attracting investments;

2) the right to demand the transfer of securities when they are placed (issued) by a person who attracts investments;

3) the right to demand the transfer of securities and the exercise of rights under these securities, which are issued by a person who attracts investments;

4) the right to demand the transfer of things (things);

5) the right to demand the transfer of exclusive rights to the result of intellectual activity or the right to use the result of intellectual activity;

6) the right to claim work and provide services.

So, we can state that the adoption of a draft law on investment platforms without a draft law on the CFA will make both of them unviable since the basic definitions used in the first bill are disclosed in the second.

The draft law on investment platforms, as its authors assume, should be in demand in hightech businesses. However, studies in different countries reveal other trends. Thus, in the USA, alternative investment is primarily attracted to the real estate sector (20 \%), technology (12 \%), food and beverages (10 \%), cinema/entertainment and retail at $7 \%$ each. In Canada, $21 \%$ in technology, $14 \%$ in public enterprises, food and beverages, e-commerce, Internet, real estate (The Americas Alternative Finance...).

Equity-based Crowdfunding is popular in technology (47 \%), Internet and e-commerce (35\%), financial sector (16\%). Revenue - sharing distribution models in retail (36\%), food and beverages (36\%), and technology (19\%). In non-investment models reward-based crowdfunding is primarily a field of art, music, and design.

One of the most famous crowdinvesting projects using the digital platform in Russia is the "Stream", realized Alpha -Bank. "Stream" uses crowdinvesting loan contract model (Alfa-Bank, a). For operations, the bank developed an Online Service Regulation (Alfa-Bank, b). The investor 
assigns the right of claim under the loan agreement to the bank for debt collection (Alfa-Bank, c). Thus, the lack of direct regulation of business goes on the way of self-regulation, forming the standards of interaction within the investment platform (Bulgakova, 2017).

The developers of the draft law on investment platforms in the explanatory note refer to the generalizations of The International Organization of Securities Commissions (IOSCO), pointing out that the bill was drafted taking into account crowdfunding approaches developed by the experience of developed countries laws.

The ways of making investments through the investment platform by the draft law on investment platforms include (part 1 of article 5):

1. $\quad$ Granting loans;

2. Acquisition of securities;

3. Acquisition of a participant's share in the authorized capital of a limited liability company, a share in the partnership company;

4. Acquisition of investment project tokens.

IOSCO distinguishes two types of crowdfunding, each of which is divided into two subspecies (Crowdfunding: An Infant Industry Growing Fast):

1. Community crowdfunding: social lending/donation crowdfunding and reward crowdfunding - the investor receives goods and services in exchange for a fee

2. $\quad$ Financial return crowdfunding (FR crowdfunding ): peer-to-peer lending (loan is issued to the borrower in exchange for interest) and equity crowdfunding (investors buy shares in the company in return for return on invested capital (capital return ratio)

In foreign analytics, there are also two types of alternative financial models: investment and non-investment (The Americas Alternative Finance...). To investment attitudes:

- Marketplace / P 2 P Consumer Lending - individual and institutional investors issue a consumer loan to a borrower (consumer borrower)

- Balance Sheet Consumer Lending - platform (platform entity) provides consumer credit directly to a borrower

- Marketplace / P 2 P Business Lending - individual and institutional investors provide loans to entrepreneurs

- Balance Sheet Business Lending - platform (platform entity) provides credit to entrepreneurs

- Marketplace / P2P Property Lending - Individual and Institutional Investors provide a loan secured by real estate to a consumer or entrepreneur

- Real Estate Crowdfunding - Individual (individual) and institutional investors (sponsors) provide capital (equity) or subordinated loan to finance real estate to a consumer or entrepreneur.

- Equity-based Crowdfunding - individual and institutional investors (sponsors) buy shares issued by the company.

- Others - less Popular: Revenue-sharing / Profit -Sharing and Debt-based Securities / Debentures

Non-investment model include (University of Cambridge):

- Reward-based Crowdfunding - Sponsors provide funding to individuals, projects, or companies in exchange for non-cash rewards or products.

- Donation-based Crowdfunding - donors and (donor s) provide funding to individuals, projects, companies have charitable or public benefit purposes irrevocably.

It is necessary take into account the trends in the development of crowdfunding, which in the next years will require international cooperation of states, the signing of international agreements, additional legal regulation (Crowdfunding: An Infant Industry Growing Fast):

- Cross-border crowdfunding

- Securitization

- Bitcoin crowdfunding

- Whole loan investments

Appeal to the experience of foreign countries can be useful in the context of the study. 
In the USA, the most popular form of crowdinvesting is $\mathrm{P}_{2} \mathrm{P}$ lending (about $94 \%$ of the total volume of crowdfunding), then reward-based crowdfunding and equity crowdfunding ( $2 \%$ each) (The Americas Alternative Finance Industry Report).

In the USA The Jumpstart Our Business Startups Act ( JOBS Act) is accepted. The impetus for the adoption of this act is considered to be the 2008 financial crisis, which led to a drop in small business activity. This act is liberalized attraction investments in startups by simplifying legal regulation in the field of securities.

For Equity crowdfunding, the United States set a new regulatory regime in order to reduce the requirements for compliance platform operators and issuers of securities while protecting investors. The following main areas of legal regulation of crowdfunding in the USA can be distinguished:

- The selection of a new type of Internet intermediary (investment platform, portal-funding portal). All crowdfunding portals must be registered with The United States Securities and Exchange Commission and the Financial Industry Regulatory Authority. The requirements for them are less stringent than for dealers and brokers. However, the portals cannot engage in certain activities, the same as the investment advicing on its web site or portal;

- the amount of funds that a company can attract through crowdfunding is limited in the sum and period of time, and company should be registered as well in the United States;

- fundraising companies are exempt from the preparation of the prospectus, but they need to disclose business information to investors in the form of an announcement of the offer, which shall contain information on the structure of capital, directors and officers, the business plan and the risks the intended use of funds and financial reporting;

- imposes restrictions for investors: those investors whose annual income or net worth of the invested assets below the threshold may invest only up to the amount specified in the law;

- Investors must complete a statement about potential risk awareness crowdfunding investments. They also have the right to refuse to investment for any reason within 48 hours before the time specified in the materials of the issuer's proposal.

In the US, there are two main models of $\mathrm{P} 2 \mathrm{P}$ lending:

1. $\quad \mathrm{P} 2 \mathrm{P}$ platforms provide loans and then hold them on their balance sheet. Platform operators must be licensed to get loans from each state in which they provide such a loan.

2. P2P-platform establish partnerships with banks to issue loans to the borrowers and then acquire loans for sale to investors in the form of investments in a particular mortgage obligation, or in the form of securities. Platform operators act as third-party service providers of banks and are subject to verification by a banking regulator. If $\mathrm{P} 2 \mathrm{P}$ operators sell loans to investors in the form of securities, they are subject to securities laws and regulations, including the preparation of a prospectus and the registration of their securities to the Securities Commission.

If the P2P-lending includes loans for individual borrowers, it is also governed by other laws and regulations on consumer credit, the upper limit of interest rates, on the protection of personal data, on the fight against e -money-laundering, in addition to the above regulations Securities Commissions.

\section{Conclusion}

In the area of crowdinvesting, the Russian legislator has a long way to go. Business is already making non-systemic attempts to establish crowdinvesting activities in Russia, as is short of credit. We believe that the need to adopt special legislation in this area is overdue, while at the same time we should not forget about the possibilities of self-regulation.

\section{References}

The Americas Alternative Finance... - The Americas Alternative Finance Industry Report [Electronic resource]. URL: https://www.jbs.cam.ac.uk/fileadmin/user_upload /research/centres/ alternative-finance/downloads/2017-06-americas-alternative-finance-industry-report.pdf

Rasporyazhenie Pravitel `stva... - Rasporyazhenie Pravitel `stva RF ot 02.06.2016 N 1083-r Ob utverzhdenii Strategii razvitiya malogo i srednego predprinimatel `stva v Rossijskoj Federacii na period do 2030 goda (vmeste s "Planom meropriyatij ("dorozhnoj kartoj") po realizacii Strategii 
razvitiya malogo i srednego predprinimatel`stva v Rossijskoj Federacii na period do 2030 goda"). [in Russian]

Zakonoproekt № 419090-7 - Zakonoproekt № 419090-7 O privlechenii investicij s ispol 'zovaniem investicionny`x platform [Elektronnyi resurs]. URL: https://sozd.duma.gov. $\mathrm{ru} / \mathrm{bill} / 419090-7$ (data obrashheniya 29.04.2019). [in Russian]

Zakonoproekt № 419059-7 - Zakonoproekt № 419059-7 O cifrovy`x finansovy`x aktivax. [Elektronnyi resurs]. URL: http://asozd2.duma.gov.ru/main.nsf/\%28Spravka\%29?Open Agent\&RN=419059-7 (data obrashheniya 29.04.2019). [in Russian]

Alfa-Bank, a- Alfa-Bank. Obrazecz dogovora zajma Potok. [Elektronnyi resurs]. URL: https://potok.digital/dogovor_v3/OU_DZ_v3.pdf (data obrashheniya 01.05.2019). [in Russian]

Alfa-Bank, b - Alfa-Bank. Reglament Onlajn ploshhadki Potok. [Elektronnyi resurs]. URL: https://potok.digital/dogovor_v3/reglament.pdf (data obrashheniya 01.05.2019). [in Russian]

Alfa-Bank, c - Alfa-Bank. Obshhie usloviya dogovora ustupki prava trebovaniya dlya celej vzy`skaniya zadolzhennosti (inkasso-cessii) Potok. [Elektronnyi resurs]. URL: https://potok. digital/dogovor_v3/terms_of_an_cession_agreement.pdf (data obrashheniya: 01.05.2019). [in Russian]

Bulgakova, 2017 - Bulgakova L.I. (2017). Razvitie samoregulirovaniya biznesa kak uslovie obnovleniya ekonomiki [Development of business self-regulation as a condition for economic renewal]. Trudy Instituta gosudarstva i prava RAN. T. 12. № 3, P. 145. [in Russian]

Crowdfunding: An Infant Industry... - Crowdfunding: An Infant Industry Growing Fast. [Electronic resource]. URL: https://www.iosco.org/research/pdf/Internetfinancepart1.pdf (data obrashheniya: 01.05.2019).

The Jumpstart Our Business... - The Jumpstart Our Business Startups Act (JOBS Act) [[Electronic resource]. URL: https://www.congress.gov/112/plaws/publ106/PLAW-112publ106.pdf (data obrashheniya: 01.05.2019). 